\title{
Studies on Maize streak virus and Maize mottle/chlorotic stunt virus in Lagos, Nigeria
}

M. A. Taiwo, Department of Botany and Microbiology, University of Lagos, Akoka, Lagos; J. d'A. Hughes, International Institute of Tropical Agriculture, Ibadan, Nigeria; and K. E. Oke, Department of Botany and Microbiology, University of Lagos, Akoka, Lagos

\begin{abstract}
Taiwo, M. A., Hughes, J. d'A., and Oke, K. E. 2006. Studies on Maize streak virus and Maize mottle/chlorotic stunt virus in Lagos, Nigeria. Plant Dis. 90:199-202.

Despite the development and deployment of maize streak-resistant (SR) germ plasm, virusinduced symptoms are still commonly observed on maize in Lagos, Nigeria. Therefore, surveys were conducted between April 2001 and February 2002 to determine the identity, prevalence, and incidence of maize viruses in 18 local government areas (LGAs) in and around Lagos by visual examination and serodiagnostic screening of symptomatic plants. All 112 fields surveyed during the dry season (September to December) and 18 fields surveyed during the late dry season (December to February) had plants infected by Maize streak virus (MSV), whereas $97.1 \%$ of the 170 fields surveyed during the wet season (April to August) had plants infected by MSV. Maize mottle/chlorotic stunt virus (MMCSV) was prevalent in 99.1, 88.9, and 67.4\% of the fields surveyed during the dry, late dry, and wet seasons, respectively. The incidence of MSV was higher in 16 of the LGAs. The highest incidence of MSV was $18.9 \%$, whereas that of MMCSV was $7.4 \%$. Serodiagnostic screening of leaf samples showing virus-induced symptoms, using antigen-coated plate enzyme-linked immunosorbent assay, indicated that 1,192/1,475 (80.8\%) and 949/1,210 (78.4\%) of the samples were positive for MSV and MMCSV, respectively. Vector transmission and host range studies confirmed the identity of the viruses. The results confirm the presence of MSV and MMCSV in Lagos and suggest that the use of MSVsusceptible cultivars is still widespread. Methods of ensuring effective utilization of existing SR germ plasm and controlling maize viruses in general are discussed.
\end{abstract}

Maize (Zea mays L.) is a major staple food crop in sub-Saharan Africa (SSA). The average yield of maize in several African countries is 1 to $1.5 \mathrm{t} / \mathrm{ha}$, only about a third of the world's average (7).

The endemic nature of some viral diseases of maize is one of the major factors responsible for low productivity (20). About 32 viruses infect maize; however, only 7 have been reported in SSA (2). Among these, Maize streak virus (MSV), genus Mastrevirus, is the most widely studied, because of its ecological versatility and high yield loss potential. It also is a major factor contributing to the instability of maize production on the continent $(7,9)$. MSV infects maize and some other members of the family Gramineae only on the African continent and adjacent islands (19).

Maize streak epidemics have been reported in Nigeria since $1966(5,8,9)$. The

Corresponding author: M. A. Taiwo

E-mail: monitaiwo@yahoo.com

* The $\boldsymbol{e}$-Xtra logo stands for "electronic extra" and indicates that Figure 1 appears in color in the online edition.

Accepted for publication 6 September 2005.

DOI: 10.1094/PD-90-0199

(C) 2006 The American Phytopathological Society pattern of streak epidemics is determined by the effect of climatic factors on the developmental and migratory activities of Cicadulina spp., because infections can be initiated only by these vectors (7). Infection of a susceptible maize cultivar by MSV results in very stunted plants with low yields.

Maize mottle/chlorotic stunt virus (MMCSV) was first reported as Maize mottle virus (MMV) by Storey (17), but a chlorotic stunt disease of maize reported in Nigeria for a number of years causes similar characteristic mottle symptoms in the early stages and was thought to be a manifestation of MMV (14). It is considered to be of major importance in Zimbabwe $(14,15,20)$. Maize is the only host of this pathogen and it is restricted to tropical African countries and the adjacent islands. MMCSV is transmitted with MSV by the same leafhopper vector (20).

The development and use of resistant maize cultivars has been recognized as the most reliable, cost-effective, and socially acceptable means of controlling MSV (7). Presently, numerous breeding programs in Africa are incorporating resistant genes identified at the International Institute of Tropical Agriculture (IITA) into their local cultivars (4). Most MSV-resistant cultivars also have moderate to high levels of resistance to MMCSV. This probably is due to co-inoculation of the two viruses by the vector during resistance screening for MSV (20).

However, despite the development and deployment of MSV-resistant (SR) cultivars, there is no accurate information on the adoption and spread of the cultivars. Although it has been reported that such cultivars are grown in Nigeria, Benin, Ghana, Cameroon, Burkina Faso, and Togo (6), virus-induced symptoms were still commonly observed on maize in Lagos state.

Due to the scant information on virus diseases of maize in Lagos and because adequate knowledge of the distribution of viruses and their strains are prerequisites for effective control through resistance, surveys were conducted to determine the prevalence and incidence of MSV and MMCSV on maize on the basis of symptomatology and serodiagnosis (18).

\section{MATERIALS AND METHODS}

Survey sites and sampling procedures. In all, 15 local government areas (LGAs) within Lagos state and 3 LGAs in neighboring Ogun state in the southwestern part of Nigeria were surveyed for MSV and MMCSV between April 2001 and February 2002. The fields surveyed varied in size from 0.2 to 4 ha and included school gardens, farmer's fields, government farm settlements, and privately owned commercial farms.

In all, 170 fields were surveyed during the wet season (April to August), 112 during the dry season (September to December), and 18 located in swampy areas were surveyed during the late dry season (December to February). The prevalence of MSV and MMCSV was determined by visually observing and recording the presence or absence of maize plants showing the symptoms of either or both viruses in each of the farms surveyed during the three seasons. MSV and MMCSV induced distinct symptoms in maize, thus simplifying the conduction of the prevalence and incidence studies. MSV induced conspicuous white chlorotic streaks along the veins on most of the leaf laminae, whereas MMCSV induced vague mottling and chlorosis on newly developing leaves, followed by shortening of the internodes, chlorosis, and stunting.

The incidence of MSV and MMCSV was determined by estimating the size of each farm and counting the number of 
maize plants showing symptoms of MSV or MMCSV as well as the total number of maize plants in small farm units. The larger farms were divided into units of $10 \mathrm{~m}^{2}$ and the survey was conducted on randomly chosen units ( 1 in every 10 units). Leaf samples from 30 symptomatic plants were collected randomly from each field. The samples from each site were sorted into two lots on the basis of symptomatology, and about five samples from each lot were randomly selected for serodiagnosis. Samples from healthy maize plants were included as controls. The samples were transported to IITA on ice and stored at $-80^{\circ} \mathrm{C}$ until needed for serodiagnosis.

Serodiagnosis. In all, 1,475 and 1,210 leaf samples putatively infected by MSV and MMCSV, respectively, were tested against their homologous antisera using antigen-coated plate enzyme-linked immunosorbent assay (ACP-ELISA) according to Koenig (10). Leaf samples were ground in extraction buffer $(0.05 \mathrm{M}$ sodium carbonate buffer, $\mathrm{pH} 9.6$, with $2 \%$ [wt/vol] polyvinylpyrrolidone). Plate wells filled with $100 \mu \mathrm{l}$ of sap were incubated, washed, and blocked with $200 \mu \mathrm{l}$ of $3 \%$ dried skimmed milk in phosphate-buffered saline with $0.5 \%$ Tween 20 (PBS-T). Cross-absorbed polyclonal antisera (100 $\mu \mathrm{l})$ was added, followed by $100 \mu \mathrm{l}$ of $1 / 30,000$ dilution of goat antirabbit immunoglobulin $\mathrm{G}$ alkaline phosphatase conju- gate (Agdia Inc., Elkhart, IN) and, finally, the substrate $p$-nitrophenyl phosphate was added. Each sample was tested in duplicate wells and each plate included positive and negative controls from IITA's stock. Absorbance at $405 \mathrm{~nm}\left(A_{405}\right)$ was measured after 60 to 90 min with a Dynex microplate reader (Dynex Technologies Inc., Chantilly, VA). Absorbance values were considered positive when the optical density readings were at least twice that of the mean for the negative control.

Transmission studies. Cicadulina mbila vectors were allowed to feed on 20 symptomatic leaf samples (10 suspected to be infected with MSV and 10 with MMCSV) for $12 \mathrm{~h}$. The inoculation access feeding was conducted by allowing viruliferous leafhoppers (five per plant) to feed on Zea mays var. Gusau pool plants for $24 \mathrm{~h}$. Mechanical transmissions using sap from the 20 symptomatic leaf samples to Z. mays, Nicotiana benthamiana Domin, $N$. tabacum L., and $N$. glutinosa L. were performed. Plants were maintained in a greenhouse at 28 to $32^{\circ} \mathrm{C}$ for 4 weeks for symptom development. Infection of inoculated plants was confirmed by ACPELISA.

\section{RESULTS}

The results of the survey showed that $98.3 \%$ of the fields were infected with MSV, whereas $80.7 \%$ were infected with

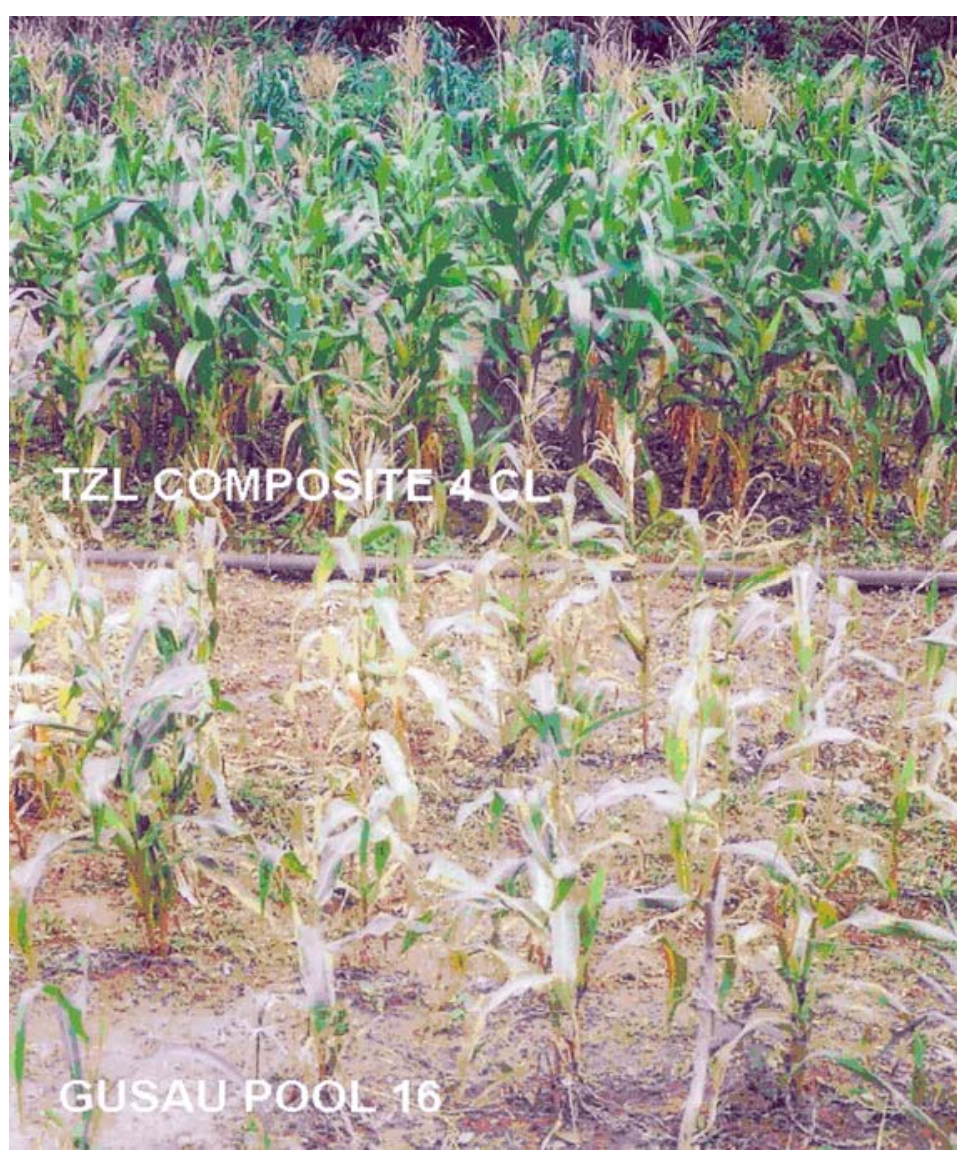

Fig. 1. Severe stunting induced by Maize streak virus in highly susceptible maize cv. Gusau pool 16 (front) and resistant cv. TZL Composite 4 CL (back).
MMCSV. Of fields surveyed during the dry and late dry seasons, $100 \%$ were infected with MSV, whereas $97.1 \%$ of the fields were infected with MSV during the wet season. The cultivation of MSVsusceptible cv. Gusau Pool 16 resulted in stunted plants and low yields compared with the resistant cv. TZL composite $4 \mathrm{CL}$ (Fig. 1). MMCSV also occurred in 99.1 and $67.6 \%$ of the fields surveyed in the dry and wet seasons, respectively (Table 1).

Virus incidence was higher during the dry and late dry seasons. Each of the 18 and 9 LGAs surveyed during the dry and late dry seasons, respectively, had plants infected by MSV, with the highest incidence $(18.9 \%)$ observed at Agege LGA (Fig. 2). The incidence of MSV during the wet season was generally less than $1 \%$ in over half of the LGAs (Fig. 2).

The observed trend of high (dry and late dry seasons) and very low (wet season) incidence for MMCSV infection was similar to that of MSV. However, the incidence of MMCSV was usually lower than that of MSV, except in Badagry LGA, where MSV was not observed during the wet season. The highest incidence for MMCSV was $7.4 \%$ at the Agege LGA (Fig. 3).

In serodiagnostic screening, the majority of the samples tested positive to their respective antisera (Table 2). Of the 1,475 samples with MSV-like symptoms, $80.8 \%$ tested positive for MSV, whereas 78.4\% of 1,210 samples with MMCSV-like symptoms tested positive. Unfortunately, none of the samples were tested against antisera to both viruses. In vector transmission tests, C. mbila transmitted MSV from all 10 samples with MSV-like symptoms, whereas MMCSV was transmitted from 8 of the 10 samples infected by MMCSV. However, none of the plants that were mechanically inoculated developed symptoms of infection. Only symptomatic plants from the vector transmission studies tested positive to their respective antisera in ELISA.

\section{DISCUSSION}

The results of this survey indicate that both MSV and MMCSV are fairly common in and around Lagos state. The high prevalence suggests that viral inocula are available in every LGA. This, coupled with the presence of vectors in abundance, the cultivation of MSV-susceptible cultivars, and conducive environmental conditions

Table 1. Effect of season on the prevalence of Maize streak virus (MSV) and Maize mottle/chlorotic stunt virus (MMCSV) in Lagos, Nigeria $^{a}$

\begin{tabular}{lcc}
\hline Season & MSV $(\%)$ & MMCSV $(\%)$ \\
\hline Wet & $165 / 170(97.1)$ & $115 / 170(67.6)$ \\
Dry & $112 / 112(100)$ & $111 / 112(99.1)$ \\
Late dry & $18 / 18(100)$ & $16 / 18(88.9)$ \\
Total & $295 / 300(98.3)$ & $242 / 300(80.7)$ \\
\hline
\end{tabular}

a Number of fields infected/number surveyed. 
(drought or irregular early rains) may result in MSV epidemics in Lagos state as have been reported in other parts of Nigeria $(5,8)$. Such irregular epidemics often cause devastating yield losses (7).

However, the incidence of both viruses in and around Lagos state is currently lower (0 to 20\%) than the higher incidence ( 24 to $76 \%$ ) previously reported in different ecological zones of Nigeria between 1983 and 1985 (16). This decrease may be attributed to the increased cultivation of SR cultivars such as Oba 2 Super hybrid maize in the LGAs which have very low incidence of MSV.
The higher incidence of both viruses observed during the dry and late dry seasons confirms the observations of Ladipo and Fakorede (11), who reported a relatively high incidence of 20 to $65 \%$ of MSV in the dry season compared with $5 \%$ for the wet season. The higher incidence of the viruses during the dry season can be attributed to the preponderance of Cicadulina spp. at the beginning of the season. Studies have confirmed that a higher proportion of viruliferous Cicadulina spp. was associated with grasses surrounding maize at the beginning of the dry season $(1,3)$. The high viral incidence associated with the dry

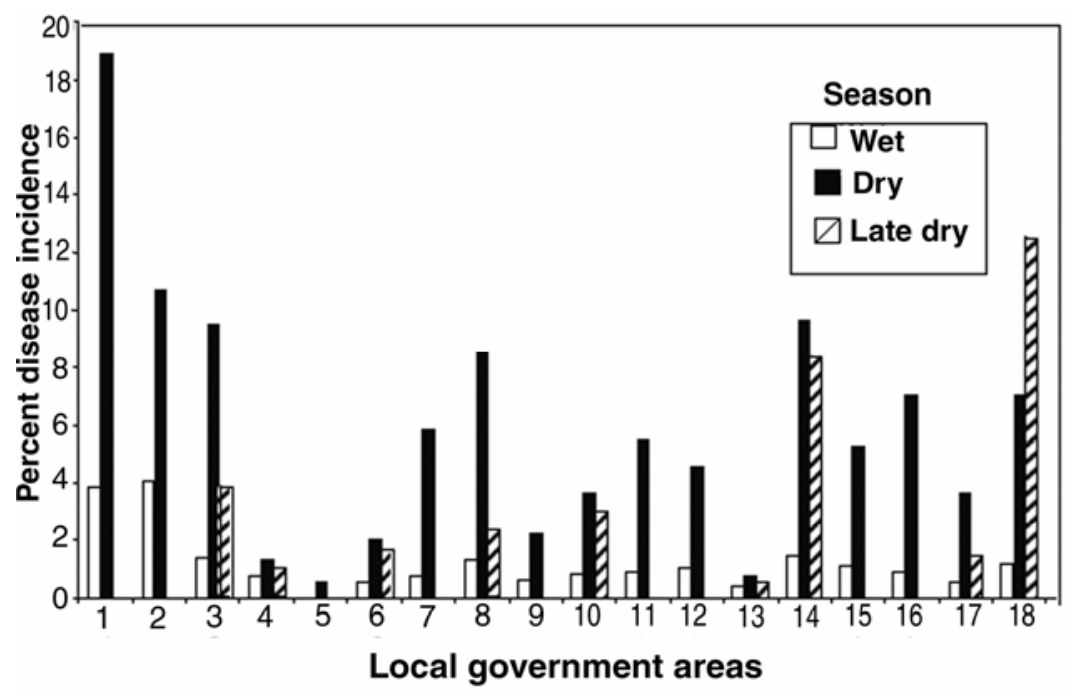

Fig. 2. Percentage incidence of Maize streak virus (MSV) during the wet, dry, and late dry seasons in 18 local government areas (LGAs) in and around Lagos state, Nigeria. LGA 1, Agege; 2, Ajeromi Ifelodun; 3, Alimosho; 4, Amuwo Odofin; 5, Badagry; 6, Epe; 7, Ifako Ijaye; 8, Ikeja; 9, Ikorodu; 10, Kosofe; 11, Mainland; 12, Mushin; 13, Ojo; 14, Oshodi Isolo; 15, Somolu; 16, Ado-Odo Ota; 17, Ifo; and 18, Obafemi Owode (LGAs 1 to 15 are located in Lagos state and 16 to 18 are located in Ogun state). Data for late dry season are from only nine LGAs.

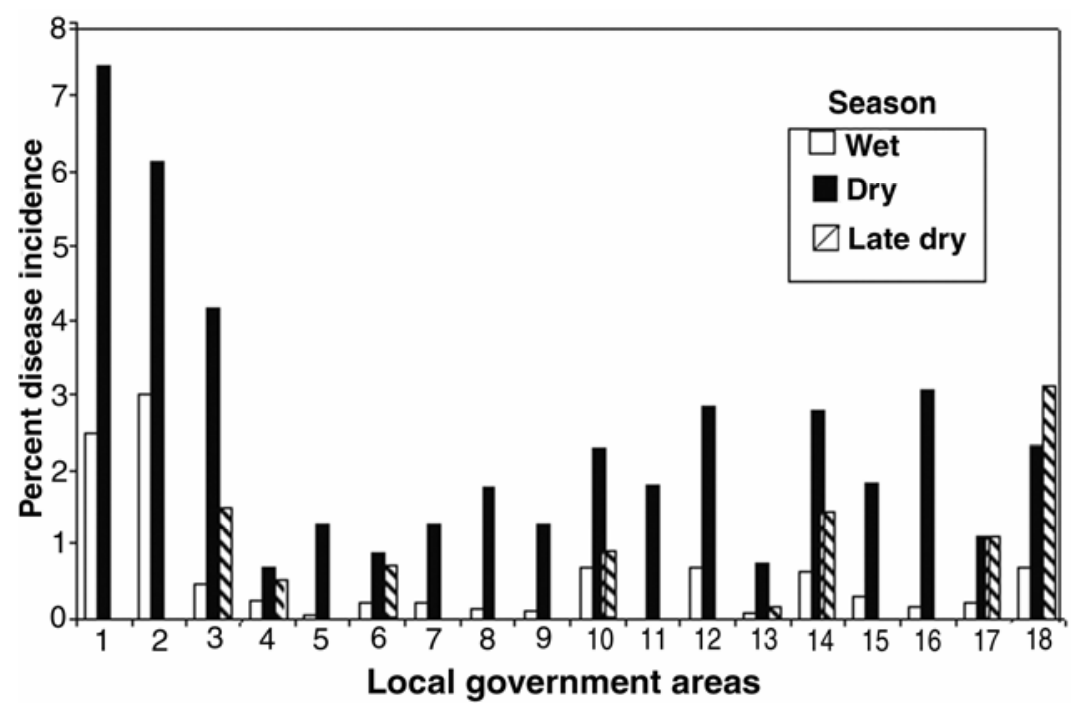

Fig. 3. Percentage incidence of Maize mottle/chlorotic stunt virus during the wet, dry and late dry seasons in 18 local government areas (LGAs) in and around Lagos state, Nigeria. LGA 1, Agege; 2, Ajeromi Ifelodun; 3, Alimosho; 4, Amuwo Odofin; 5, Badagry; 6, Epe; 7, Ifako Ijaye; 8, Ikeja; 9 , Ikorodu; 10, Kosofe; 11, Mainland; 12, Mushin; 13, Ojo; 14, Oshodi Isolo; 15, Somolu; 16, Ado-Odo Ota; 17, Ifo; and 18, Obafemi Owode (LGAs 1 to 15 are located in Lagos state and 16 to 18 are located in Ogun state). Data for late dry season are from only nine LGAs.

season maize portends a great problem. The dry season maize crop constitutes the bulk of the grains used for human consumption and livestock feed in Nigeria, because such grains usually are left on the field to dry without fear of loss from fungal attack (11). The lower incidence observed during the wet season is due to the heavy rainfall which may be responsible for vector mortality, or the increased number of alternative hosts for the vectors during this period (1).

Visual identification generally was adequate for determining the etiology of the symptoms of the collected field samples. This was further corroborated by ELISA, although about $20 \%$ of the symptomatic plants tested negative to the antisera of the suspected viruses. This may be due to the presence of the viruses in low concentration in such samples or the presence of other viruses in maize in Lagos state. Alternatively, it may have been due to the presence of serologically variable strains of the viruses tested, even though the polyclonal antisera used in this survey were known to be fairly broad spectrum in reactivity. Although studies by Peterschmitt (13) suggest that all MSV isolates belong to the same serological group, Mesfin (12) showed that 19 of 24 isolates from grasses and cereal crops reacted with a polyclonal antiserum to a severe MSV isolate from maize, thus suggesting serological differences. There is a need for further investigation to ascertain which of these reasons is responsible for the negative serological reactions.

Losses due to MSV could be minimized if national programs adequately deploy available SR cultivars. Factors contributing to low use of SR cultivars include apathy by the predominantly peasant growers, preference for the traditional maize cultivars passed on from generation to generation, and the widespread use of unimproved production technologies, all of which result in poor yield. Training and reorientation of growers to be more receptive of the SR cultivars, as well as increased efficiency in the multiplication and distribution of SR and other improved hybrid seeds, are needed to encourage their widespread cultivation.

\section{ACKNOWLEDGMENTS}

We thank O. Nzenkwe for her excellent technical assistance.

Table 2. Detection of Maize streak virus (MSV) and Maize mottle/chlorotic stunt virus (MMCSV) in collected field samples using antigen-coated plate enzyme-linked immunosorbent assay ${ }^{\mathrm{a}}$

\begin{tabular}{lcc}
\hline Season & MSV (\%) & MMCSV (\%) \\
\hline Wet & $673 / 825(81.6)$ & $448 / 575(77.9)$ \\
Dry & $447 / 560(79.8)$ & $439 / 555(79.1)$ \\
Late dry & $72 / 90(80.0)$ & $62 / 80(77.5)$ \\
Total & $1,192 / 1,475(80.8)$ & $949 / 1,210(78.4)$ \\
\hline
\end{tabular}

${ }^{a}$ Number of infected plants/number tested. 


\section{LITERATURE CITED}

1. Asanzi, C. M., Bosque Perez, N. A., Buddenhagen, I. W., Gordon, D. T., and Nault, L. R. 1994. Interactions among maize streak virus, leafhopper vector population and maize cultivar in forest and savanna zones of Nigeria. Plant Pathol. 43:145-157.

2. Brunt, A. A., Crabtree, K., and Gibbs, A. 1990. Viruses of Tropical Plants. Wallingford, CAB International, Oxon, UK

3. Dabrowski, Z. T., Nwilene, F., and Kumar, R. 1991. First regular observation on leafhoppers Cicadulina spp. vectors of maize streak virus in South Eastern Nigeria. Insect Sci. Appl. 12:249-261.

4. Efron, Y., Kim, S. K., Fajemisin, J. M., Mareck, J. M., Tang, C. Y., Dabrowski, Z. T., Rossel, H. W., Thottappilly, G., and Buddenhagen, I. W. 1989. Breeding for resistance to maize streak virus: A multidisciplinary team approach. Plant Breed. 103:1-36.

5. Esenam, U. 1966. Observations on the maize streak disease in Western Nigeria. Niger. Agric. J. 3:38-41

6. Fajemisin, J. M. 1992. Outline of national maize research systems in West and Central Africa. Ouagadougou, Burkina Faso: SemiArid Food Grain Research and Development Project (SAFGRAD)/International Institute of Tropical Agriculture (IITA), Ibadan, Nigeria.

7. Fajemisin, J. M. 2003. Overview of maize viruses in sub-Saharan Africa. Pages 158-171 in: Plant Virology in sub-Saharan Africa, Proc. Conf. Organized by IITA. J. d'A. Hughes and J. Odu, eds. International Institute of Tropical Agriculture, Ibadan, Nigeria.

8. Fajemisin, J. M., Cook, G. E., Okusanya, F., and Shoyinka, S. A. 1976. Maize streak virus epiphytotic in Nigeria. Plant Dis. Rep. 60:443-447.

9. Fajemisin, J. M., and Shoyinka, S. A. 1977. Maize streak and other virus diseases in West Africa. Pages 52-61 in: Proc. Int. Maize Virus Dis. Colloquium and Workshop. D. T. Gordon, L. R. Nault, and L. E. Williams, eds. Ohio Agricultural Research and Development Centre, Wooster, OH.

10. Koenig, R. 1981. Indirect ELISA methods for the broad specificity detection of plant viruses. J. Gen. Virol. 55:53-62.

11. Ladipo, J. L., and Fakorede, M. A. B. 1992. Influence of seasonal changes on the incidence of maize streak virus disease at the Obafemi Awolowo University teaching and research farm. Niger. J. Plant Prot. 14:62-69.

12. Mesfin, T., Bosque-Perez, N. A., Buddenhagen, I. W., Thottappilly, G., and Olojede, S. O. 1992. Studies of maize streak virus isolates from grass and cereal hosts in Nigeria. Plant Dis. 76:789-795.

13. Peterschmitt, M., Reynaud, B., Sommermeyer, G., and Baudin, P. 1991. Characterization of maize streak virus isolates using monoclonal and polyclonal antibodies and by transmission to a few hosts. Plant Dis. 75:27-32.

14. Rossel, H. W., Buddenhagen, I. W., and Thottappilly, G. 1980. Storey's maize mottle virus rediscovered? IITA Res. Briefs 1:2-4.

15. Rossel, H. W., and Thottappilly, G. 1983 Maize chlorotic stunt in Africa: A manifestation of maize mottle virus? Pages 158-160 in: Proc. Int. Maize Virus Dis. Colloquium and Workshop. D. T. Gordon, L. R. Nault, and L. E. Williams, eds. Ohio Agricultural Research and Development Centre, Wooster, $\mathrm{OH}$.

16. Rossel, H. W., and Thottappilly, G. 1985. Virus Diseases of Important Food crops in Tropical Africa. International Institute of Tropical Agriculture, Ibadan, Nigeria.

17. Storey, H. H. 1937. A new virus of maize transmitted by Cicadulina spp. Ann. Appl. Biol. 24:87-94.

18. Taiwo, M. A., Hughes, J. d'A., and Oke, K. E. 2004. Incidence and prevalence of Maize streak virus (MSV), genus Mastrevirus and Maize mottle/chlorotic stunt virus in Lagos, Nigeria. (Abstr.) Phytopathology 94:S101.

19. Thottappilly, G. 1992. Plant virus disease of importance to African agriculture. J. Phytopathol. 134:265-288.

20. Thottappilly, G., Bosque-Perez, N. A., and Rossel, H. W. 1993. Viruses and virus diseases of maize in tropical Africa. Plant Pathol. 42:494-509. 